International Journal of English Literature and Social Sciences
Vol-6, Issue-5; Sep-Oct, 2021
Journal Home Page Available: https://ijels.com/
Journal DOI: $10.22161 /$ ijels

Peer-Reviewed Journal

\title{
An Analysis of Prepositional related errors in English Composition of Upper Primary Learners in Kieni East Sub County in Nyeri County
}

\author{
Rosepaulah Wairimu ${ }^{1}$, Dr. Beth Njeri Ngugi PhD ${ }^{2}$
}

${ }^{1}$ School of Social Sciences, Department of Languages and Humanities, Mount Kenya University, Kenya

${ }^{2}$ Department of Humanities and communication studies, Murang'a University of Technology, Murang'a, Kenya

Received: 09 Aug 2021; Received in revised form: 09 Sep 2021; Accepted: 18 Sep 2021; Available online: 21 Sep 2021

(C)2021 The Author(s). Published by Infogain Publication. This is an open access article under the CC BY license

(https://creativecommons.org/licenses/by/4.0/).

\begin{abstract}
The research sought to investigate prepositional errors on English usage. There has been a big outcry in the field of English language learning about the falling levels of proficiency in English among students, particularly in upper primary level. This problem was attributed to inadequate mastery of linguistic skills and incomplete acquisition of English language. Therefore, the current paper investigated preposition errors as manifested in written compositions of upper primary learners. Prepositional rules in English language are inconsistent; that is certain prepositions can be applied in one form, but not in another. More so, prepositions are polysemous. Thus, learners often become frustrated when they have to determine prepositional meanings and when to use them appropriately. The research was guided by the following objectives; identifying prepositional related errors in learners' composition and describing the errors. The study applied Corder's(1974, 1976) Error Analysis Theory. The study adopted a descriptive research design in order to vividly describe various errors encountered in the usage of English prepositions. The target population was 52 primary schools, 168 teachers of English, and 408 pupils from Public Primary Schools in Kieni-East Sub County in Nyeri County. Data was collected using interview guides for the teachers and composition test for pupils. The study showed four main prepositional errors; errors of omission, addition, substitution and misordering. The study concludes that prepositional errors are more of lexical errors since they affect the meaning of the entire sentence. Thus, the study recommends that learners should be taught rules of prepositions systematically and that a revision of course books should provide specific rules that may lead to proper acquisition of prepositions.
\end{abstract}

Keywords-Errors, Prepositions, Prepositional errors.

\section{INTRODUCTION}

Language is a social aspect of human life and a fundamental part of human life in society. Brown (2007) defines a language as a tool for expressing ideas or relating information and messages to other people. While communicating with others, people have to use language properly and correctly to convey their intentions without any mistakes and errors. One of the languages that people use to communicate in the world is English. In Kenya, English is one of the subjects taught in educational system and is also the medium of instruction. Learning English involves all four language skills which are fundamental to speak and understand a language. These four skills are listening, reading, speaking and writing. Brown (2000) notes that to become proficient in the English language, learners must acquire an adequate understanding and ability for the four basic skills: listening, speaking, reading and writing. Celce-Murcia \&Olshtain, (2000) note that among these language skills, writing is the most difficult because it requires a higher level of productive language control. Writing requires more effort to master than other language skills because writers must compose sentences 
and be knowledgeable of appropriate vocabulary to convey his/her intended meaning in an organized and coherent format (Shawish, 2009).

Moreover, writing requires a range of vocabulary; syntax and morphology that make learners produce many types and numbers of errors. An error refers to a systematic deviation from a selected norm or set of norms (Corder, 1974). Brown (2007) defines an error as an "identifiable alteration of the grammatical elements of a native speaker," which is simply an utterance that differs from a native speaker.Corder $(1974$, p.125) argues that the study of errors is part of the investigation of the process of language learning.

Speaking and writing are productive skills. The learners have to master it more to communicate with other people in the world. Moreover, learners need to master vocabulary and grammar. Among the grammatical aspects that learners have to master are verbs, nouns, adjectives, articles, gerunds, preposition, and others. However, conducting or using all the items is not easy and when speaking and writing all the items have to be used appropriately in order to construct an accepted structure in English. This study focused on errors of prepositions in written compositions. Prepositions are a group of words prefixed to nouns. According to Fera (2019), a preposition is a word or set of words which indicates location or some other relationship between a noun and a pronoun and other parts of a sentence. Prepositions have also been defined as particles that precede a noun. Nikroo; Behjat and Zareian (2016) identify two types of English prepositions; spatial (space) and temporal (time) prepositions. Spatial prepositions can be defined as space words. Spatial prepositions have also been defined as prepositions that enable speakers to communicate object locations. Some of the spatial prepositions include to, from, across, along, toward, via, past, into, onto, and out of. Furthermore, some of the space prepositions include near, far, inside and above. Temporal prepositions show time. Prepositions under this category include during, in, on, at, for, from, after, and before.

Extensive research in linguistics has illustrated difficulties associated with the usage of English prepositions. Thilakaratne (1992) observes that in English, prepositions are words, while in Sinhala they are represented as spatial postpositions or as suffixes (locative, ablative Case). Rubic (2004) also observes that Prepositional rules in English language are inconsistent; that is certain prepositions can be applied in one form, but not in another. Thus, the English Language Learner (ELL) will not understand the reason behind these rules while native speakers do not know the explanation either (Rubic, 2004). More so, prepositions are polysemous. That is they have more than one meaning. Koffi (2010) states that learners often become frustrated when they have to determine prepositional meanings and when to use them appropriately. Lorincz (2012) observes that English language learners find prepositions challenging to master due to its large numbers and different nature.

Sotiloye, Bodunde and Olayemi (2015) articulated that the difficulties in the use of English prepositions were mostly to do with wrong use of preposition 'on' with other prepositions such as 'in', 'at', 'over', 'for', 'by', 'with', 'to' usually influenced by L1 meaning. Hameed (2019) carried out a survey among Iraqi EFL learners and not only acknowledges that learning English prepositions is difficult and slow but also pointed out that among the important tips in learning English prepositions is to determine errors associated with their use. Alaina (2019) in her study of document analysis of undergraduate documents pinpoint the importance of error analysis in determining errors in the usage of English prepositions. Other studies that show problematic nature of acquisition of prepositions include Nurhayati and Nurdini (2019 and Sari (2019) where the findings of the study clarified the fact that students make errors in terms of vocabulary, use of prepositions and also incomplete sentences.

In Kenya there has been a big outcry in the field of English language learning and particularly in the falling levels of proficiency in English among pupils in upper primary level. The Kenya national examination council reports of the year 2018 and 2019 noted that many candidates' essays were characterized by wrong word choice, wrong grammar and spelling in their writing in English. This problem was attributed to inadequate mastery of linguistic skills and incomplete acquisition of English language. It is noted that the candidates cannot write error-free sentences. Writing skill is considered as one of the vital skill in learning. However, in English language writing has been perceived as the most difficult skill among the four skills. Even a native speaker fails to write a good piece of writing. Consequently, it is a very hard task for second language learners in Kenya. More so, it is unavoidable to find errors made by this group of learners since they have a limited chance to write in English. Thus, the present paper was set to investigate grammatical errors and more specifically prepositions which are a tool used to make a sentence to become meaningful and to connect it to another sentence.

The study was guided by the following research objectives:

i. To identify the prepositional related errors in the learners' composition in Kieni East Sub County in Nyeri County. 
ii. To describe prepositional errors are committed in learners' composition in Kieni East Sub County in Nyeri County.

According to Corder (1967) the understanding of learners' errors is necessary for language teachers, researchers, and learners. The learner corpora can provide information on learners' common errors and pedagogical purposes. Thus, understanding these errors enabled the researcher to identify the most affected areas and come up with effective ways for Teachers of English to correct them. It is hoped that the findings of the study will be of benefit to both English language teachers as well as pupils and that the study will add to the existing literature in Applied Linguistics and more so in Error Analysis studies. Thus, this study benefits both the teachers and the students.

\section{ERROR ANALYSIS THEORY}

This paper applied Error Analysis Theory (EAT) as propounded by (Corder, 1974, 1976). Error analysis focuses on errors committed by the language users on various aspects of the grammatical structures of the sentences. This theory is further developed by Ellis (1994). Error Analysis (EA) was started byCorder in early 70 's. Corder alludes that errors made by learners could give clues about the language systems in use or language learnt in L1. Error analysis approach aims at observing, analyzing and classifying the deviations in the rules of SL and revealing the systems it is operating on (Brown, 1994). Thus, EA systematically interprets the unacceptable forms produced by SL learners. The theory also emphasizes on the significance of errors (Ellis, 1994). First, Errors are significant since they provide information about the much that learners have learnt, second they give insight into how language learning takes place and lastly they are a means through which learners discover target language. Corder (1981) identifies the processes that simplify the EAT study as discussed in the sections that follow below:

\subsection{Selection of language sample}

The first stage of the theory involves collection of sample data from the learner of a given language. The researcher collected specific samples of learners language use by giving a guided composition where the topic was controlled. The learners wrote a composition that had the following beginning:

The day I had been waiting for finally arrived. I woke up excited.....

\subsection{Identification of errors}

The second stage of the theory involves identification of errors in the sample, which is a stage that basically involves only the errors to be identified and not the mistakes. This is a relevant step since it makes the error analysis system highly developed and elaborative hence reliable while it retains its simplicity. Error identification is simply defined as awareness of the presence of the error since it is easy to capture written errors and miss out on the spoken errors. According to (Richards, 1971), there is a wide variation when it comes to detection rates since people tend to overlook errors where they are obvious and vice versa.

The researcher identified errors by analysing correct interpretation of the learners intended meaning within the context. The identified errors were used as data for this study. According to Richards (1971), errors can be classified as either local or global depending on their magnitude of effect. This stage was important in objective where the researcher was set to identify the prepositional errors.

\subsection{Description of Errors}

Description of errors is a comparative process as it entails comparing the erroneous forms made by learners with the correct form of Target Language. The purpose of the third stage of the theory is to carry out description of errors which is based on a variety of linguistic aspects such as phonology, morphology, syntax, and semantics among others. The researcher identified the incorrect sentence and identified and categorized errors in terms of types of prepositional errors.

\subsection{Explanation of Errors}

The fourth stage of the theory involves explanation of the errors which basically focuses on identification of causes of the errors especially interlingual, intralingual as well as aspect of developmental interference. The researcher explained errors described in terms of the causes such as transfer, ignorance of rules or false hypothesis.

\subsection{Evaluation of Errors}

The fifth and last stage of the theory focuses mainly on evaluation of errors, which is a stage that involves the assessment of the seriousness of the errors and also takes into consideration any relevant and remedial decisions as well as pedagogical measures aimed at addressing the challenges.

\section{RESEARCH METHODOLOGY}


This research adopted descriptive research design to analyze prepositional errors in written compositions of upper primary learners in Kieni East sub county, Nyeri County. Research design is a plan adopted in a particular research or a set of methods and procedures that can be used in collection and analysis of variables being measured in a research problem (Cresswell, 2012). Descriptive analysis entails description of the data in its present form (Cresswell, 2003; 2012). According to Kothari (2004) descriptive analysis is composed of raw data transformed in a form that is easy to comprehend and explain rearranged, organized, and manipulated data that produce descriptive information. The researcher, in the present study was set to identify, categorize and describe prepositional errors in the written compositions of the learners based on Corder's Error Analysis (1971) as discussed in section 2 of this paper.

This study was carried out in Nyeri County; particularly in Kieni East Sub County. The current study found this area viable for the research since through classroom observation by the researcher there are cases of L1 influence to L2 in both written and spoken English. The respondents of the study were 56 teachers of English and 136 standard 8 pupils from a section randomly selected schools in Kieni East Sub County. Their ages ranged from 13 to 16 years old with an equal gender presence. Standard 8 pupils were chosen because the curriculum guide set by the ministry of Education reflects that standard 8 pupils should be able to produce less error free written compositions.

The study used two data collection instruments namely, interviews and compositions. An interview schedule was used to interview the teachers. This schedule consisted of semi-structured questions. The interview schedule was more of a guide and questions were asked directly as they appear on the schedule. This allowed in-depth probing of matters to do with the choice made and the reasons given for the choice of a particular teaching strategy in upper primary. During the interview with the teachers, the researcher recorded responses in three ways; by taking notes in a note book where detailed descriptions of the responses were noted down, by the use of a voice recorder. The voice recorder served as a backup for the information that was written down during the interview. The third method was by ticking in the appropriate box and/or writing down the responses in short form in the spaces available in the interview schedule.

The second way that was used to collect data was through composition test. One way of testing writing skills is through composition tests. Tests are used to measure human behavior and they are important in experimental and descriptive studies in education. The researcher used an achievement test. The researcher tested written production by giving a composition to learners with an intention of testing on grammar (prepositional usage). A composition test was administered to standard 8 pupils to test their performance in grammar and more particularly preposition usage. A checklist was given to teachers made it easier for them to identify several grammatical errors. Besides, Armstrong\& Green (2018) suggests that checklists in research help in enhancing evidence and decision making on research hypothesis.

\section{RESULTS AND DISCUSSION \\ 4.1 Identification of the prepositional related errors}

The first objective in this study was to identify prepositional related errors. An error is the performance failure (Corder, 1971). Nordquist (2018) observes that errors can be a faulty, controversial, or unconventional usage of grammatical element. The first and second stage in EAT are collection of the samples of the students' language (i.e. deciding what outputs of the learner's language can be used for the analysis and how to collect the data.

The researcher identified the errors in the compositions that were marked by the teachers. Identification refers to the selection of sentences that depicted errors of prepositions as shown in table 1 below:

Table 1: Identification and classification of errors

\begin{tabular}{|l|l|l|}
\hline No & Identified sentence or phrase & $\begin{array}{l}\text { Classification } \\
\text { errors }\end{array}$ \\
\hline $\mathbf{1}$ & $\begin{array}{l}\text { Incorrect: My uncle promised us that the car would depart in 9.00 am. } \\
\text { Correct: } \text { My uncle promised us that the car would depart at 9.00 am. }\end{array}$ & Selection/substitution \\
\hline $\mathbf{2}$ & $\begin{array}{l}\text { Incorrect: } \text { When I arrived home there were so many people in home. } \\
\text { Correct: } \text { When I arrived home there were so many people at home. }\end{array}$ & Selection/substitution \\
\hline $\mathbf{3}$ & $\begin{array}{l}\text { Incorrect: } \text { My mother was in shamba } \\
\text { Correct: } \text { My mother was at the shamba }\end{array}$ & Selection/substitution \\
\hline
\end{tabular}




\begin{tabular}{|c|c|c|}
\hline 4 & $\begin{array}{l}\text { Incorrect: There was noise in house. } \\
\text { Correct: There was noise at the house. }\end{array}$ & Selection/substitution \\
\hline 5 & $\begin{array}{l}\text { Incorrect: My first day in the city was scary. } \\
\text { Correct: My first day at the city was scary. }\end{array}$ & Selection/substitution \\
\hline 6 & $\begin{array}{l}\text { Incorrect: My parents were in pay roll. } \\
\text { Correct: My parents were on pay roll. }\end{array}$ & Selection/substitution \\
\hline 7 & $\begin{array}{l}\text { Incorrect: By then my aunt was not going to work because she was in leave. } \\
\text { Correct: By then my aunt was not going to work because she was on leave. }\end{array}$ & Selection/substitution \\
\hline 8 & $\begin{array}{l}\text { Incorrect: When I approached, I saw so many people in compound. } \\
\text { Correct: When I approached, I saw so many people on the compound. }\end{array}$ & Selection/substitution \\
\hline 9 & $\begin{array}{l}\text { Incorrect: The landlord sent us from the house we had rented since my parents did not } \\
\text { pay in time. } \\
\text { Correct: The landlord ejected us from the house we had rented since my parents did not } \\
\text { pay on time. }\end{array}$ & Selection/substitution \\
\hline 10 & $\begin{array}{l}\text { Incorrect: It was early in the morning when the sun had risen from the East. } \\
\text { Correct: It was early in the morning when the sun had risen in the East. }\end{array}$ & Selection/substitution \\
\hline 11 & $\begin{array}{l}\text { Incorrect: My uncle was missing from Friday. } \\
\text { Correct: My uncle was missing since Friday. }\end{array}$ & Selection/substitution \\
\hline 12 & $\begin{array}{l}\text { Incorrect: That day it rained from morning } \\
\text { Correct: That day it rained since morning }\end{array}$ & Selection/substitution \\
\hline 13 & $\begin{array}{l}\text { Incorrect: Life became unbearable when my dad died from lung cancer. } \\
\text { Correct: Life became unbearable when my dad died of lung cancer. }\end{array}$ & Selection/substitution \\
\hline 14 & $\begin{array}{l}\text { Incorrect: Lucy had failed from sciences } \\
\text { Correct: Lucy had failed in sciences }\end{array}$ & Selection/substitution \\
\hline 15 & $\begin{array}{l}\text { Incorrect: The man had a daughter of his former wife. } \\
\text { Correct: The man had a daughter by his former wife. }\end{array}$ & Selection/substitution \\
\hline 16 & $\begin{array}{l}\text { Incorrect: What is the time in your watch? I asked. } \\
\text { Correct: What is the time by your watch? I asked. }\end{array}$ & Selection/substitution \\
\hline 17 & $\begin{array}{l}\text { Incorrect: My sister was born at 1st January } 2012 . \\
\text { Correct: My sister was born on 1st January } 2012 .\end{array}$ & Selection/substitution \\
\hline 18 & $\begin{array}{l}\text { Incorrect: That morning I had set the alarm clock to go off on } 7 \text { am. } \\
\text { Correct: That morning I had set the alarm clock to go off at } 7\end{array}$ & Selection/substitution \\
\hline 19 & $\begin{array}{l}\text { Incorrect: The parents meeting terminated on } 12 \text { o'clock. } \\
\text { Correct: The parents meeting terminated at } 12 \text { o'clock. }\end{array}$ & Selection/substitution \\
\hline 20 & $\begin{array}{l}\text { That night I had dreamt with my late mum. } \\
\text { That night I had dreamt about my late mum. }\end{array}$ & Selection/substitution \\
\hline 21 & $\begin{array}{l}\text { Incorrect: I had nothing to eat so I bought one Mandazi with } 5 \text { shillings. } \\
\text { Correct: I had nothing to eat so I bought one Mandazi for } \mathbf{5} \text { shillings. }\end{array}$ & Selection/substitution \\
\hline 22 & $\begin{array}{l}\text { Incorrect: My uncle did not agree to me. } \\
\text { Correct: My uncle did not agree with me. }\end{array}$ & Selection/substitution \\
\hline
\end{tabular}




\begin{tabular}{|c|c|c|}
\hline 23 & $\begin{array}{l}\text { Incorrect: While I was strolling, I saw the kidnapper in the way. } \\
\text { Correct: While I was strolling, I saw the kidnapper on the way. }\end{array}$ & Selection/substitution \\
\hline 24 & $\begin{array}{l}\text { Incorrect: My uncle died in } 20^{\text {th }} \text { March } 2020 . \\
\text { Correct: My uncle died on } 20^{\text {th }} \text { March } 2020 .\end{array}$ & Selection/substitution \\
\hline 25 & $\begin{array}{l}\text { Incorrect: The man was going in the house. } \\
\text { Correct: The man was going into the house. }\end{array}$ & Selection/substitution \\
\hline 26 & $\begin{array}{l}\text { Incorrect: The thief hit my dadon his head. } \\
\text { Correct: The thief hit my dadonto his head. }\end{array}$ & Selection/substitution \\
\hline 27 & $\begin{array}{l}\text { Incorrect: We had an event at school in Monday. } \\
\text { Correct: We had an event at school on Monday. }\end{array}$ & Selection/substitution \\
\hline 28 & $\begin{array}{l}\text { Incorrect: I found the money on the table. } \\
\text { Correct: I found the money at the table. }\end{array}$ & Selection/substitution \\
\hline 29 & $\begin{array}{l}\text { Incorrect: } \quad \text { When I approached the city, I saw the tallest building of the world. } \\
\text { Correct: }\end{array}$ & Selection/substitution \\
\hline 30 & $\begin{array}{l}\text { Incorrect: Like the Wiseman says, "'the key of happiness is having dreams.'" } \\
\text { Correct: Like the Wiseman says, "'the key to happiness is having dreams.', }\end{array}$ & Selection/substitution \\
\hline 31 & $\begin{array}{l}\text { Incorrect: I could not tell the difference of the two buildings. } \\
\text { Correct: I could not tell the difference between the two buildings. }\end{array}$ & Selection/substitution \\
\hline 32 & $\begin{array}{l}\text { Incorrect: That year my father was to takecourse of teaching. } \\
\text { Correct: That year my father was to takein teaching. }\end{array}$ & Selection/substitution \\
\hline 33 & $\begin{array}{l}\text { Incorrect:Njoroge was a student at Muranga boys. } \\
\text { Correct: Njoroge was a student of Muranga boys. }\end{array}$ & Selection/substitution \\
\hline 34 & $\begin{array}{l}\text { Incorrect: There was a lot of food at the wedding that consisted from Pilau and fruit. } \\
\text { Correct: There was a lot of food at the wedding thatconsisted of Pilau and fruit. }\end{array}$ & Selection/substitution \\
\hline 35 & $\begin{array}{l}\text { Incorrect: My uncle was accused for murdering his wife. } \\
\text { Correct:My uncle was accused of murdering his wife. }\end{array}$ & Selection/substitution \\
\hline 36 & $\begin{array}{l}\text { Incorrect: My Dad used to meet my uncle in the living room. } \\
\text { Correct: My Dad used to meet my uncle at the living room. }\end{array}$ & Selection/substitution \\
\hline 37 & $\begin{array}{l}\text { Incorrect: I was not good in Maths. } \\
\text { Correct: I was not good at Maths. }\end{array}$ & Selection/substitution \\
\hline 38 & $\begin{array}{l}\text { Incorrect: The teacher asked us toSign in the bottom. } \\
\text { Correct: The teacher asked us toSign at the bottom. }\end{array}$ & Selection/substitution \\
\hline 39 & $\begin{array}{ll}\text { Incorrect: } & \text { The stranger was in the phone. } \\
\text { Correct: } & \text { The stranger was on the phone. }\end{array}$ & Selection/substitution \\
\hline 40 & $\begin{array}{l}\text { Incorrect: The class prefect spoke in behalf of our class. } \\
\text { Correct: The class prefect spoke on behalf of our class. }\end{array}$ & Selection/substitution \\
\hline 41 & $\begin{array}{ll}\text { Incorrect: } & \text { The stranger got on the taxi. } \\
\text { Correct: } & \text { The stranger got into the taxi. }\end{array}$ & Selection/substitution \\
\hline 42 & Incorrect: The teacher promised to look at the matter. & Selection/substitution \\
\hline
\end{tabular}




\begin{tabular}{|c|c|c|}
\hline & Correct: The teacher Promised to look into the matter. & \\
\hline 43 & $\begin{array}{l}\text { Incorrect: We were just on time to catch the train. } \\
\text { Correct: We were just in time to catch the train. }\end{array}$ & Selection/substitution \\
\hline 44 & $\begin{array}{ll}\text { Incorrect: } & \text { I saw the news on the newspapers. } \\
\text { Correct: } & \text { I saw that news in the newspapers. }\end{array}$ & Selection/substitution \\
\hline 45 & $\begin{array}{ll}\text { Incorrect: } & \text { My uncle was afraid from snakes. } \\
\text { Correct: } & \text { My was afraid of snakes }\end{array}$ & Selection/substitution \\
\hline 46 & $\begin{array}{l}\text { Incorrect: When the kidnapper was caught, he was ashamed for himself. } \\
\text { Correct: When the kidnapper was caught, he was ashamed of himself. }\end{array}$ & Selection/substitution \\
\hline 47 & $\begin{array}{ll}\text { Incorrect: } & \text { Njeri was incapable to take care of herself. } \\
\text { Correct: } & \text { Njeri was incapable of taking care of himself. }\end{array}$ & Selection/substitution \\
\hline 48 & $\begin{array}{ll}\text { Incorrect: } & \text { He didnt listen me. } \\
\text { Correct: } & \text { He didnt listen to me }\end{array}$ & Omission \\
\hline 49 & $\begin{array}{ll}\text { Incorrect: } & \text { Do you want to try this blue dress? } \\
\text { Correct: } & \text { Do you want to try on this blue dress? }\end{array}$ & Omission \\
\hline 50 & $\begin{array}{ll}\text { Incorrect: } & \text { We feasted different type's food. } \\
\text { Correct: } & \text { We feastedon different types of food. }\end{array}$ & Omission \\
\hline 51 & $\begin{array}{l}\text { Incorrect: The man knocked the door. } \\
\text { Correct: } \quad \text { The man knocked at the door. }\end{array}$ & Omission \\
\hline 52 & $\begin{array}{ll}\text { Incorrect: } & \text { We waited a car. } \\
\text { Correct: } & \text { We waited for a car. }\end{array}$ & Omission \\
\hline 53 & $\begin{array}{l}\text { Incorrect: } \quad \text { Bought me a new dress. } \\
\text { Correct: } \quad \text { Bought for me new dress. }\end{array}$ & Omission \\
\hline 54 & $\begin{array}{lr}\text { Incorrect: } & \text { Arrived school } \\
\text { Correct: } & \text { Arrived at school }\end{array}$ & Omission \\
\hline 55 &  & Omission \\
\hline 56 & $\begin{array}{l}\text { Incorrect: Dressed my uniform } \\
\text { Correct: Dressed in my uniform }\end{array}$ & Omission \\
\hline 57 & $\begin{array}{l}\text { Incorrect: Jumped on him } \\
\text { Correct: Jumped onto him }\end{array}$ & Omission \\
\hline 58 & $\begin{array}{l}\text { Incorrect: Looking myself } \\
\text { Correct: Looking at myself }\end{array}$ & Omission \\
\hline 59 & $\begin{array}{l}\text { Incorrect: The ceremony started } 10 \text { o'clock } \\
\text { Correct: The ceremony started at } 10 \text { o'clock }\end{array}$ & Omission \\
\hline 60 & $\begin{array}{l}\text { Incorrect: I was waiting you } \\
\text { Correct: I was waiting for you }\end{array}$ & Omission \\
\hline 61 & $\begin{array}{l}\text { Incorrect: They waited the occasion to begin. } \\
\text { Correct: They waited for the occasion to begin. }\end{array}$ & Omission \\
\hline
\end{tabular}




\begin{tabular}{|c|c|c|}
\hline 62 & $\begin{array}{l}\text { Incorrect: Reached at the stage } \\
\text { Correct: Reached the stage }\end{array}$ & Addition/insertion \\
\hline 63 & $\begin{array}{l}\text { Incorrect: Contribute for some money } \\
\text { Correct: Contribute some money }\end{array}$ & Addition/insertion \\
\hline 64 & $\begin{array}{l}\text { Incorrect: Enter in the bus } \\
\text { Correct: Enter the bus }\end{array}$ & Addition/insertion \\
\hline 65 & $\begin{array}{l}\text { Incorrect: Sit into our seat } \\
\text { Correct: Sit }\end{array}$ & Addition/insertion \\
\hline 66 & $\begin{array}{l}\text { Incorrect: Boarded on the bus } \\
\text { Correct: Enter the bus }\end{array}$ & Addition/insertion \\
\hline 67 & $\begin{array}{l}\text { Incorrect: Getting near to the church } \\
\text { Correct: Getting near the church }\end{array}$ & Addition/insertion \\
\hline 68 & $\begin{array}{l}\text { Incorrect: Returned back home } \\
\text { Correct: Returned home }\end{array}$ & Addition/insertion \\
\hline 69 & $\begin{array}{l}\text { Incorrect: Shut off the door } \\
\text { Correct: Shut the door }\end{array}$ & Addition/insertion \\
\hline 70 & $\begin{array}{l}\text { Incorrect: On the next day } \\
\text { Correct: The next day }\end{array}$ & Addition/insertion \\
\hline 71 & $\begin{array}{l}\text { Incorrect: Boarded on the bus } \\
\text { Correct: Boarded the bus }\end{array}$ & Addition/insertion \\
\hline 72 & $\begin{array}{l}\text { Incorrect: Rushed into the hospital } \\
\text { Correct: Rushed to the hospital }\end{array}$ & Addition/insertion \\
\hline 73 & $\begin{array}{l}\text { Incorrect: The thief entered into the kitchen. } \\
\text { Correct:The thief entered the kitchen. }\end{array}$ & Addition/insertion \\
\hline 74 & $\begin{array}{l}\text { Incorrect: My father loves with my mother. } \\
\text { Correct: My father loves my mother. }\end{array}$ & Addition/insertion \\
\hline 75 & $\begin{array}{l}\text { Incorrect: The doctor recommends her to take this pill. } \\
\text { Correct: The doctor recommends that she take this pill. }\end{array}$ & Addition/insertion \\
\hline 76 & $\begin{array}{l}\text { Incorrect:The kidnapper demanded we answer to his question. } \\
\text { Correct: The kidnapper demanded we answer his question. }\end{array}$ & Addition/insertion \\
\hline 77 & $\begin{array}{l}\text { Incorrect: I was waiting forthe judge to decide upon the case. } \\
\text { Correct: I was waiting forthe judge to decide the case. }\end{array}$ & Addition/insertion \\
\hline 78 & $\begin{array}{l}\text { Incorrect: I decided to avoid to making the kidnapper angry. } \\
\text { Correct: I decided to avoid making the kidnapper angry. }\end{array}$ & Addition/insertion \\
\hline 79 & $\begin{array}{l}\text { Incorrect: It was on a busy town } \\
\text { Correct: It was in a busy town }\end{array}$ & Misformation \\
\hline 80 & $\begin{array}{l}\text { Incorrect: Splashed me with water } \\
\text { Correct: Splashed water on me }\end{array}$ & Misformation \\
\hline 81 & Incorrect: Annoyed about me & Misformation \\
\hline
\end{tabular}




\begin{tabular}{|c|c|c|}
\hline & Correct: Annoyed with me & \\
\hline 82 & $\begin{array}{l}\text { Knock on the door } \\
\text { Knock at the door }\end{array}$ & Misformation \\
\hline 83 & $\begin{array}{l}\text { Incorrect:On the next hour } \\
\text { Correct:In the next hour }\end{array}$ & Misformation \\
\hline 84 & $\begin{array}{l}\text { Incorrect: Invited in our house } \\
\text { Correct: Invited to our house }\end{array}$ & Misformation \\
\hline 85 & $\begin{array}{l}\text { Correct: Trip in Nairobi } \\
\text { Incorrect: Trip to Nairobi }\end{array}$ & Misformation \\
\hline 86 & $\begin{array}{l}\text { Incorrect: People in the party } \\
\text { Correct: People at the party }\end{array}$ & Misformation \\
\hline 87 & $\begin{array}{l}\text { Incorrect: To sit in the back } \\
\text { Correct: To sit at the back }\end{array}$ & Misformation \\
\hline 88 & $\begin{array}{l}\text { Incorrect: The teacher requested the class monitor todivide the oranges between the } \\
\text { children in class. } \\
\text { Correct: The teacher requested the class monitor todivide the oranges among the } \\
\text { children in class. }\end{array}$ & Misformation \\
\hline 89 & $\begin{array}{ll}\text { Incorrect: } & \text { Please wait inside the white line. } \\
\text { Correct: } & \text { Please wait behind the white line. }\end{array}$ & Misformation \\
\hline 90 & $\begin{array}{l}\text { Incorrect: I had to agree with the kidnappers' demands. } \\
\text { Correct: I had to agree to the kidnappers' demands. }\end{array}$ & Misformation \\
\hline 91 & $\begin{array}{l}\text { Incorrect: Splashed me with water } \\
\text { Correct: Splashed water on me }\end{array}$ & Misordering \\
\hline 92 & $\begin{array}{l}\text { Incorrect: Told me to woke up } \\
\text { Correct: Woke me up }\end{array}$ & Misordering \\
\hline 93 & $\begin{array}{l}\text { Incorrect: Told me to woke up } \\
\text { Correct: Woke me up }\end{array}$ & Misordering \\
\hline
\end{tabular}

Table 1 shows that 93 prepositional related errors were identified in the compositions that the researcher collected. The 93 errors were classified in terms of Selection/substitution, omission, addition/insertion, misformation and misordering. The frequency and percentage of the errors that were shown in table 2 below:

Table 2: Frequency and percentage of errors

\begin{tabular}{|l|l|l|}
\hline Types of errors & Frequency & Percentage \\
\hline Selection/Substitution & 47 & 51 \\
\hline Omission & 14 & 15 \\
\hline Insertion/addition & 17 & 18 \\
\hline Misformation & 12 & 13 \\
\hline Misordering & 3 & 3 \\
\hline Total & 93 & 100 \\
\hline
\end{tabular}


Table 2 above shows that five types of errors occurred in learners prepositions; selection/substitution $(51 \%)$, omission (15\%), insertion/addition (18\%) misformation $(12 \%)$ and misordering $(3 \%)$. The above results show that the most frequent prepositional error that occurred in standard 8 marked composition is selection/substitution (47 errors that is $51 \%$ ). The above results show that prepositions usage imposes a remarkable difficulty for learners which are parallel to the previous studies (Sotiloye, Bodunde and Olayemi 2015; Hameed 2019 and Alaina 2019). The majority of errors were selection/substitution errors $(51 \%)$ This finding is similar to Hameed (2019) and Alaina (2019) who found that selection/substitution errors were the most frequent errors in the data that was collected. Alaina observed that selection errors occurred in all kinds of preposition. This is similar to the present study that found that selection errors occurred in errors in adverbial preposition, errors Particles, and errors in functional prepositions as presented in table 1. The reason is because of the polysemic nature of prepositions or the intended meaning of the writer. For instance, we sat at the beach, on the beach, by the beach or near the beach. The current study found that learners show confusion in the use of in and at, in and on, from and of as shown in table 1. The correct and incorrect form in table 1 shows that, learners confuse on the choice of preposition because of lack of mastery of prepositional rules and the ubiquitous nature of prepositions.

\subsection{Description of prepositional errors}

The second objective of this paper was set to describe the identified prepositional errors committed in compositions by upper primary learners in Kieni East Sub County in Nyeri County.According to error analysis theory description of errors is a comparative process as it entails comparing the erroneous forms made by learners with the correct form of Target Language. Thus, description of errors also involves explanation of the errors which basically focuses on identification of causes of the errors especially interlingual, intralingual as well as aspect of developmental interference. Following Corder (1973, 1974, and 1976) and Dulay, Burt, \&Kransen (1982) prepositional errors were discussed in terms of omission, addition, substitution, misformation, and misordering. The researcher identified and classified errors, thereafter the frequency of occurrence is summarised Table 2 below:

\subsubsection{Omission of preposition}

The data collected depicted errors of omission (15\%) as shown in table 2. Corder (1973) defines omission errors as omission on of some required element. According to Dulay et al (1982) a sentence is erroneous when there is an absence of an item. Thus, errors of omission are described as "the absence of an item that must appear in a well-formed Utterance" (Dulay, et al 1982: 154). The data collected show that learners omit prepositions hence they affect the meaning of the sentence. Learners of upper primary made omission since they did not know there were components or certain other words that must appear in their sentences. Most errors were made in using prepositions as reflected in the data below:

Incorrect: $\mathrm{He}$ didnt listen me. Correct: $\mathrm{He}$ didnt listen to me.

Incorrect: Do you want to try this blue dress? Correct: Do you want to try on this blue dress?

In the sentences above the prepositions to and on which should be obligatory items in the sentence have been omitted by the learners. Various researchers show that second language learners in general omit or misuse English prepositions (Scott and Tucker, 1974; Alaina, 2019) and this may be due to mother tongue interference. The error in the first sentence also occurs because the verb 'listen' 'He didnt listen to me' requires a prepositional introduced by 'to' while in the second example the noun phrase this blue should be introduced by a preposition. The examples show cases of spoken form of English. The data collected also show that omission errors are due to transfer of L1 knowledge to L2 as shown below:

Incorrect: We waited a car Correct: We waited for a car

Incorrect: Bought me a new dress Correct: Bought for me new dress

Some omission errors were due to direct translation from L1 to L2. In the sentences below the verb went, dress and look need prepositions in order to communicate appropriately but the learners omit them. These errors occur due to literal translation from L1 to L2 as shown below:

Incorrect: Went in the bush Correct: Went into the bush

Incorrect: Dressed my uniform Correct: Dressed in my uniform

These sentences showed that the learners omitted prepositions while using English prepositions. The above data shows omissions of prepositions such as to, on at, for, into and in. Such prepositions are important in the formation of adverbial prepositions that show time, place, and manner

\subsubsection{Errors of addition}

The data collected also reflects preposition errors of addition are (18\%). According to Corder (1973) addition 
errors are addition of some unnecessary or incorrect element. Prepositions errors of addition are characterized by the presence of an item that must not appear in a wellformed utterance (Dulay, Burt, \&Kransen, 1982). The data shows that learners added prepositions where they were not needed. The first preposition that was unnecessarily added or inserted where it was not needed is 'into' as shown below:

Incorrect: Rushed into the hospital Correct: Rushed to the hospital

Incorrect: The thief entered into the kitchen. Correct: The thief entered the kitchen.

The above examples show that the preposition 'into' was inserted unnecessarily in a position where it is not required. The above errors occurred due to lack of knowledge about zero prepositions and these errors are caused due to direct translation by learners from L1 to L2. More so, errors of addition were as a result of ignorance of rule of restrictions by learners, especially where a zero preposition is required as shown:

Incorrect: Reached at the stage Correct: Reached the stage

Incorrect: Contribute for some money Correct: Contribute some money

The verb reach, contribute and enter do not require prepositions therefore the preposition at and for and in the sentences above have been unnecessarily used. Therefore, the learners have used redundant use of prepositions. The errors in the above sentences occur because the verb reach and contribute require a direct object rather than a prepositional phrase. Learners tend to forget these rules hence they commit mistakes. Addition errors in the data collected were committed due to overgeneralization of prepositional rules as shown in the examples below:

Incorrect: Boarded on the bus Correct: Enter the bus

Incorrect: Getting near to the church Correct: Getting near the church

\section{Incorrect: Returned back home Correct: Returned} home

The use of prepositions on, to and back have been overgeneralized and this may be due to in adequate learning of rules. Learners also create deviant structures from their previous knowledge of other structures of L2 as shown in the examples below:

Incorrect: My father loves with my mother. Correct: My father loves my mother.

Incorrect: The doctor recommends her to take this pill. Correct: The doctor recommends that she take this pill.
From the data above, it is clear that errors of addition occur due to direct L1 to L2 translation, L1 interference, ignorance to restriction rules and overgeneralizations. These results are in line with Adewuyi's (2001) study that found that some of the factors that lead to prepositional errors were linguistic factors, misuse of prepositions and poor application of rules.

\subsubsection{Prepositional errors of substitution/selection}

According to Corder (1973) substitution is the selection of an incorrect element. The data collected also showed errors of selection/substitution. Errors of selection (51\%) were the most committed errors due to ignorance of rules. First the data reflectedsubstitution of the preposition in for at, and in for on in certain contexts as shown below:

Incorrect: My Dad used to meet my uncle in the living room. Correct: My Dad used to meet my uncle at the living room.

Incorrect: I was not good in Maths. Correct: I was not good at Maths.

Substitution was also shown in cases where the preposition in was replaced by on as indicators of certain objects like, days, seasons, years, items or date as shown below:

Incorrect: The teacher asked us toSign in the bottom. Correct: The teacher asked us toSign at the bottom.

Incorrect: The stranger was in the phone. Correct: The stranger was on the phone.

Incorrect: The class prefect spoke in behalf of our class. Correct: The class prefect spoke on behalf of our class.

The above data shows misuse of prepositions by learners and this is due to the polysemic nature of prepositions. These finding is in line with Fitikides (2002) study that found that one key problem with the use of prepositions is that second language learners confuse their meaning by using one preposition instead of another. The learners also had problems with prepositions use due to their many meanings. This finding was in line with Swan (2005) who states that a preposition like at has 18 main uses listed in the dictionary list thus a learner will find difficulties whether to use it or not as shown below:

Incorrect: The teacher promised to look at the matter.

Correct: The teacher promised to look into the matter

The data collected also show interference of mother tongue. For instance, the preposition with isa case of mother tongue interference in the sentence below:

Incorrect: $\mathrm{He}$ is married with Eunice. Correct: $\mathrm{He}$ is married to Eunice. 
Other prepositions that show mother tongue interference are on, from and for in the sentences below:

Incorrect: I saw the news on the newspapers. Correct: I saw that news in the newspapers.

Incorrect: My uncle was afraid from snakes. Correct: My uncle was afraid of snakes.

Incorrect: When the kidnapper was caught, he was ashamed for himself.

Correct: When the kidnapper was caught, he was ashamed of himself

\subsubsection{Errors ofmisformation}

The fourth type of error in a preposition is misformation (13\%). Dulay et al (1982) state that misformation error is the incorrect presence of an item in an utterance. Errors of misinformation are close to errors of substitution. Errors of misformation were due to lack of mastery of application of rules. The data below show examples of prepositional errors of misformation.

Incorrect: It was on a busy town Correct: It was in a busy town

Incorrect: Splashed me with water Correct: Splashed water on me

Incorrect: Annoyed about me Correct: Annoyed with me

\subsubsection{Errors of Misodering}

The last type of preposition errors that was discussed in the study was Misordering (3\%). Corder (1973) calls it permutation which is the misordering of elements. According to Dulay, Burt, \&Kransen, 1982) permutation is characterized by incorrect placement of morpheme or a group of morphemes in an utterance. The data collected shows that misordering prepositions are caused by mother tongue interference as shown below:

Incorrect: Splashed me with water Correct: Splashed water on me

Incorrect: Told me to woke up Correct: Woke me up

From the research findings of section 4.3, the study concludes that the causes of the errors are mainly interlingual, intralingual or aspect of developmental interference. Interlingual transfer occurs when learners make errors because of L1 interference while intralingual transfer occurs without reffering to L1 sources. For instance, when the learner attempts to apply a rule learnt during the target language class. For instance, preposition in and at are a part of preposition of place and time. However, it is used for more particular place or time. The researcher found that learners made errors while using the two prepositions. For example, "He was told to sit in the back of the class", the learner should have written," He was told to sit at the back of the class". These errors of misformation are intralingual errors since the learner have not fully mastered the rules of the language. The learner instead misapplies a rule learnt in the use of prepositions. Prepositions also have many meanings therefore, learners may get frustrated when determining prepositional meanings and trying to use them appropriately (cf. Koffi, 2010). Moreover, the polysemous nature of prepositions makes the task of mastering rather difficult. This is because preposition might bear multiple meanings depending on the given context, and similarly some verbs might require an obligatory preposition.

\section{CONCLUSION}

The current study was designed to analyse prepositional errors in written English of upper primary learners: a case study of Kieni East sub county, Nyeri County, Kenya. Basing on the findings, learners have more errors in use of adverbial prepositions which lead them to cause errors of substitution. Since there are so many, prepositional errors may definitely occur due to incomplete learning of prepositional rules. The study also concludes that prepositions are challenging unit in learning of English due to their high degree of polysemy. Hence, teachers of should provide creative techniques in the teaching and learning of prepositions.

\section{REFERENCES}

[1] Alaina, N. (2019). An Error Analysis on The Writing Sentence Preposition of the 2018 abstract Undergraduate Thesis English Students of IAIN Metro (Doctoral dissertation, IAIN Metro).

[2] Brown, H. D. (1994). Teaching by Principles: Interactive language teaching methodology. New York: Prentice Hall Regents.

[3] Brown, H. D. (2000). Principles of Language Learning and Teaching (forth Edition). New York: Pearson Education, Inc.

[4] Brown, H. D. (2007). Principles of Language Learning and Teaching (Fifth Edition). New York: Pearson Education, Inc.

[5] Celce-Muriama, M and Olshtain, E. (2000). Discourse and Context in Language Teaching: A Guide for Language Teachers. Cambrige: Cambridge University Press.

[6] Corder, S. P. (1967). The significance of learner's errors. International Review of Applied Linguistics in Language Teaching, 5(4), 161-170. https://doi.org/10.1515/iral.1967.5.1-4.161

[7] Corder, S. (1971). Idiosyncratic dialects and error analysis. International Review of Applied Linguistics, 9(2), 147-160.

[8] Corder, S.P. (1973). Introducing Applied Linguistics. Harmondsworth: Penguin. 
[9] Corder, S.P. (1974). Error Analysis, In Allen, J.L.P. and Corder, S.P. (1974). Techniques in Applied Linguistics. Oxford: Oxford University Press.

[10] Corder, S. P. (1981). Error analysis and interlanguage. Oxford: Oxford Oxford University Press.

[11] Creswell, J. W. (2012). Qualitative inquiry and research design: Choosing among the five traditions (3 rd ed.). California: Thousand Oaks.

[12] Creswell, J. W. (2003). Research design: Qualitative, quantitative, and mixed method approaches. Lincoln: University of Nebraska.

[13] Cuyckens, H., \&Radden, G. (ed.) (2002). Perspectives on Prepositions. Tübingen: Niemeyer.

[14] Dulay, H., Burt M. \&Krashern, S. (1982). Language two. New York: Oxford University.

[15] Ellis, R. (1994). The study of second language acquisition. London: Oxford University Press.

[16] Fera, A. (2019). Lexical Ambiguity Compared to Syntatic / or Structural 208 Ambiguity. International Journal, Vol 30(5), 1113 - 1116.

[17] Fitikides, T.J. (2002). Common Mistakes in English. London: Pearson Education Limited.

[18] Hameed, B. A. (2019). Investigation of Iraqi EFL Learners' Ability to Explain English Prepositions. Journal of AlFrahedis Arts, (23), 411-427.

[19] Koffi, E. (2010). Applied English syntax: Foundations for word, phrase and sentence analysis. Dubuque, Iowa: Kendall Hunt Publishing Company.

[20] Kothari, C (2004). Research Methodology: Methods and Techniques (2nd Ed.). New Delhi: New Age International Publishers.

[21] Littlefield, H. (2009). A fine-grained approach to lexical and functional syntactic categories: Evidence from English prepositions and their acquisition. Mauritius: VDM Publishing House Ltd.

[22] Lorincz, K., \& Gordon, R. (2012). Difficulties in Learning Prepositions and Possible Solutions. Linguistic Portfolios 1(14)1. Retrieved from:

[23] http://repository.stcloudstate.edu/cgi/viewcontent.cgi?articl $\mathrm{e}=1012$ \& context=stclo ud_ling, it is vital that teachers develop effective instructional methods.

[24] Nikroo, M., Bahjat, F and Zorean, A. Investigating the Use of Games and Flash Cards in Teaching Spatial and Temporal Prepositions to Iranian Pre-Intermediate EFL Learners. Journal of studies in learning and teaching English, vol 5-89-104.

[25] Nordquist, R. (2015, January 15). Grammatical Error Definition and Examples. Retrieved January 18, 2018, from http://www.thoughtco.com/grammatical-errorusage 1690911

[26] Nurhayati, S., \&Nurdini, R. A. (2019). Error Analysis on EFL Students Independent Writing Task of TOEFL iBT. English and Literature Journal, 6(2), 159-172.

[27] Richards, J. C. (1971). A non-contrastive approach to Error Analysis. English Language Teaching Journal, 25, 204-219.

[28] Sari, D. M. M. (2019). An Error Analysis on Student's Translation Text. Eralingua: JurnalPendidikanBahasaAsingdanSastra, 3(2).
[29] Scott, M., \& Tucker, G.R. (1974). Error Analysis and English Language Strategies of Arab Students. Language Learning. 24 (1): 69-97

[30] Shawish, J. A (2009). Analysis and Assessment of Palestinian EFL Majors' Written English. Unpublished Ph. D. Thesis. Sudan University of Science and Technology, Sudan.

[31] Sotiloye, B. S., Bodunde, H., \&Olayemi, O. (2015). English language prepositions: An Albatross for English Language learners In Nigeria. International Journal of English and Literature, 6(6), 103-108.

[32] Tilakaratne, S. (1992). Spatial expressions in Sinhala: Appearance of verb forms. Kanas Working papers in Linguistics, 17(1 \& 2), $159-162$. 